
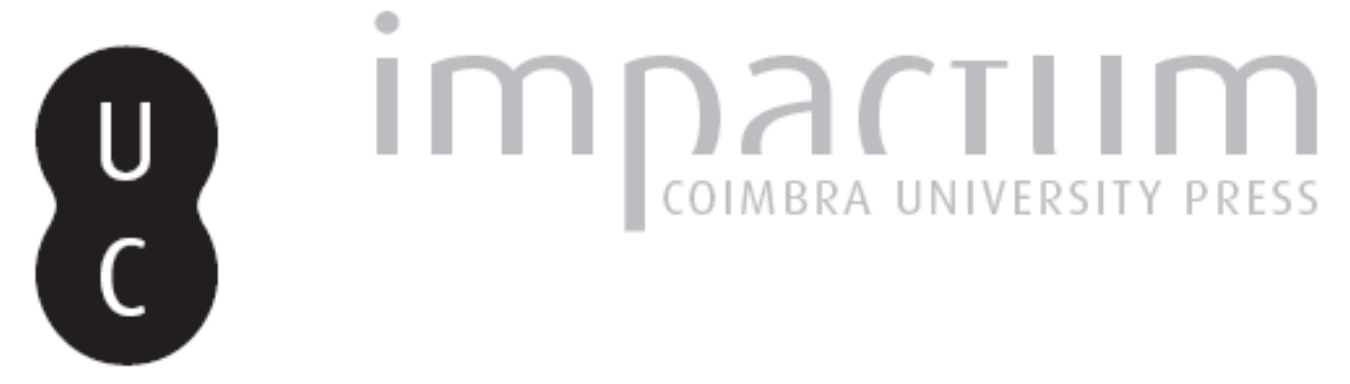

O parque ecológico do Funchal e a prevenção de cheias e incêndios florestais
Autor(es):
Quintal, Raimundo
Publicado por: Associação Portuguesa de Riscos, Prevenção e Segurança
URL persistente:
URI:http://hdl.handle.net/10316.2/40112
DOI:
DOl:https://doi.org/10.14195/1647-7723_7_5
Accessed : $\quad$ 26-Apr-2023 04:51:25

A navegação consulta e descarregamento dos títulos inseridos nas Bibliotecas Digitais UC Digitalis, UC Pombalina e UC Impactum, pressupõem a aceitação plena e sem reservas dos Termos e Condições de Uso destas Bibliotecas Digitais, disponíveis em https://digitalis.uc.pt/pt-pt/termos.

Conforme exposto nos referidos Termos e Condições de Uso, o descarregamento de títulos de acesso restrito requer uma licença válida de autorização devendo o utilizador aceder ao(s) documento(s) a partir de um endereço de IP da instituição detentora da supramencionada licença.

Ao utilizador é apenas permitido o descarregamento para uso pessoal, pelo que o emprego do(s) título(s) descarregado(s) para outro fim, designadamente comercial, carece de autorização do respetivo autor ou editor da obra.

Na medida em que todas as obras da UC Digitalis se encontram protegidas pelo Código do Direito de Autor e Direitos Conexos e demais legislação aplicável, toda a cópia, parcial ou total, deste documento, nos casos em que é legalmente admitida, deverá conter ou fazer-se acompanhar por este aviso.
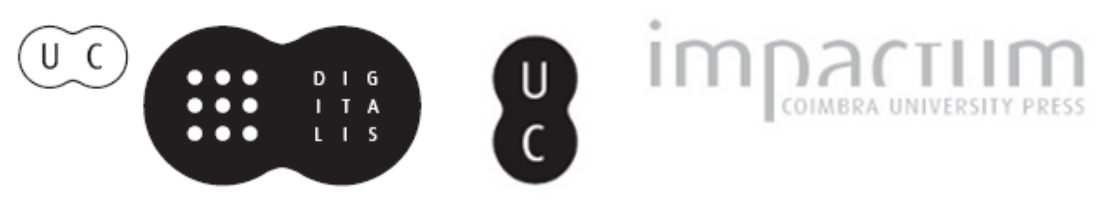


\title{
O parque ecológico do Funchal e a prevenção de cheias e incêndios florestais
}

\author{
Raimundo guintal *
}

\begin{abstract}
Resumo:
O Parque Ecológico do Funchal ocupa uma área de $10 \mathrm{Km}^{2}$ na zona montanhosa sobranceira à cidade. A vasta propriedade municipal esteve durante muitos anos sujeita a um intenso pastoreio e à expansão descontrolada dos eucaliptos. Em 1994 foi criado o Parque e arrancou o processo de repovoamento florestal com espécies indígenas. O retorno da floresta primitiva contribuirá para reduzir os fogos, diminuir a erosão e baixar os riscos de cheias violentas no Funchal.

Palavras chave:

Erosão, pastoreio, cheias, repovoamento florestal, educação ambiental, prevenção de fogos florestais, espécies indigenas.
\end{abstract}

\section{Résumé:}

Le Parc Écologique du Funchal s'étend par une aire de $10 \mathrm{Km} 2$ sur les montagnes à coté de la ville. Pendant beaucoup d'années, cette grande propriété municipale a été soumise au pâturage intensif et à une expansion non controlée de I'eucaliptus. En 1994, le Parc a été créé et le processus de repeuplement forestier avec des espèces indigènes a commencé. Le retour de la forêt primitive contribuera à la rédution des incendies et de l'érosion ainsi qu'à la baisse des risques d'inondations rapides dans la ville de Funchal.

Mots clés:

Érosion, pâturage, inondations, repeuplement forestier, éducation environnementale, prévention d'incendies forestiers, espèces indigènes.

\begin{abstract}
:
The Ecological Park of Funchal has $10 \mathrm{~km} 2$ on the mountains surrounding the town. During many years, this big municipal propriety suffered intensive pasture and a non controlled expansion of eucaliptus. In 1994, the Park was created and the resettlement with native specimens began. Returning of primitive forest will contribute to the reduction of forest fires and erosion, as well as flash floods in the town of Funchal.

Key words:

Erosion, pasture, flash floods, forest resettlement, environmental education, forest fires prevention, native specimens.
\end{abstract}

\section{Introdução}

O Parque Ecológico do Funchal é ainda muito jovem. Nasceu em 1994, na vertente sul da Ilha da Madeira, abarcando os terrenos dos antigos Montados do Barreiro e do Pisão(Mapa 1). O Parque Ecológico do Funchal estende-se desde as proximidades do Pico do Areeiro (1818 metros de altitude) até à confluência do Córrego do Pisão com a Ribeira de Santa Luzia, apenas 500 metros acima do nível do mar. Tem uma área de quase 1000 hectares $\left(10 \mathrm{Km}^{2}\right)$. Entre o pico do Areeiro e o extremo sul do Parque distam 5500 metros, em projecção horizontal, e 1300 metros, na vertical (Mapa 2).

\footnotetext{
* Geógrafo. Vereador do Ambiente, Educação e Ciência da Câmara Municipal do Funchal
}

A expressão MONTADO no Continente é utilizada para identificar uma mata de sobreiros ou de azinheiras, ou destas duas espécies em comum. Na Madeira a palavra tem outra carga significativa. Trata-se dum terreno de montanha, arborizado ou não.

O Montado do Barreiro, com uma área de cerca de 700 ha, foi adquirido por expropriação em 1918 com o objectivo de aproveitar as águas das suas nascentes para abastecer a cidade do Funchal.

Em 1927, a Câmara do Funchal iniciou os trabalhos de arborização do montado municipal, seguindo as directrizes do plano elaborado peloengenheiro agrónomo Abílio Barros e Sousa que, logo na descrição geral da extensa faixa de terreno localizado na montanha sobranceira à cidade, fazia esta elucidativa consideração: - "É terreno baldio de que os povos do Monte e da Corujeira se utilizam abusivamente para pastagem 


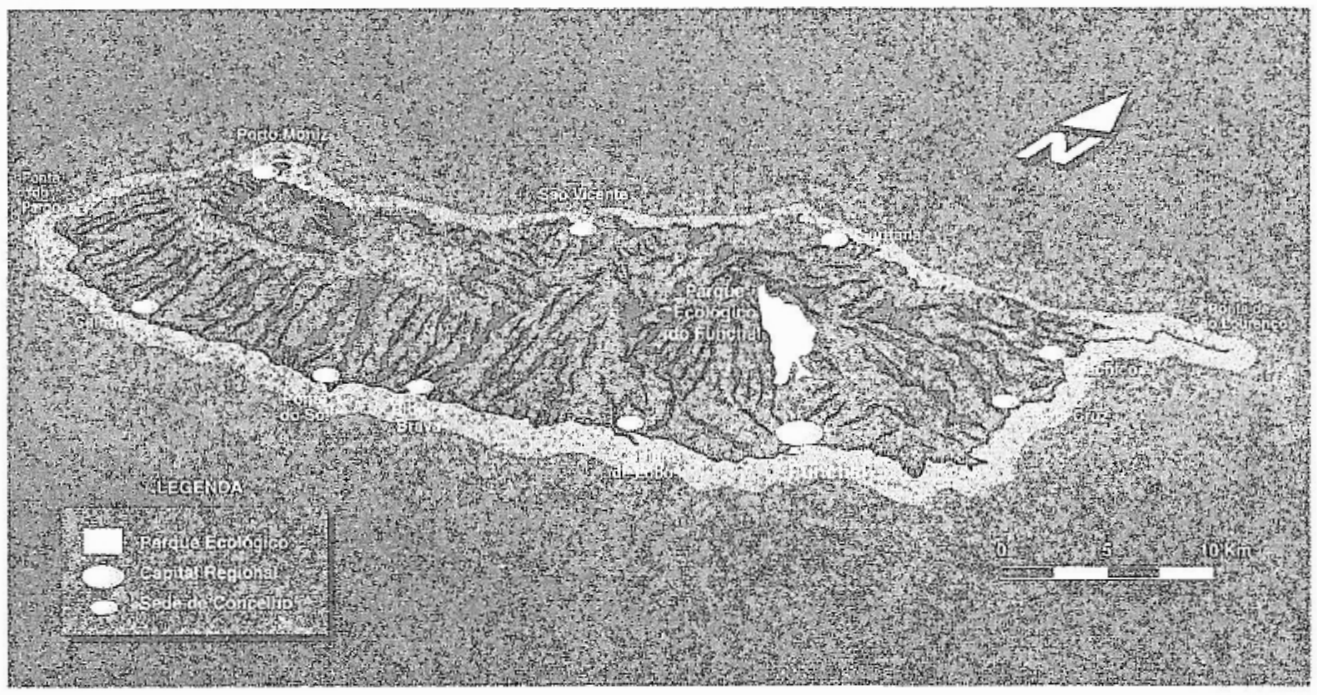

Mapa 1 - Ilha da Madeira com a localização do Parque Ecológico do Funchal.

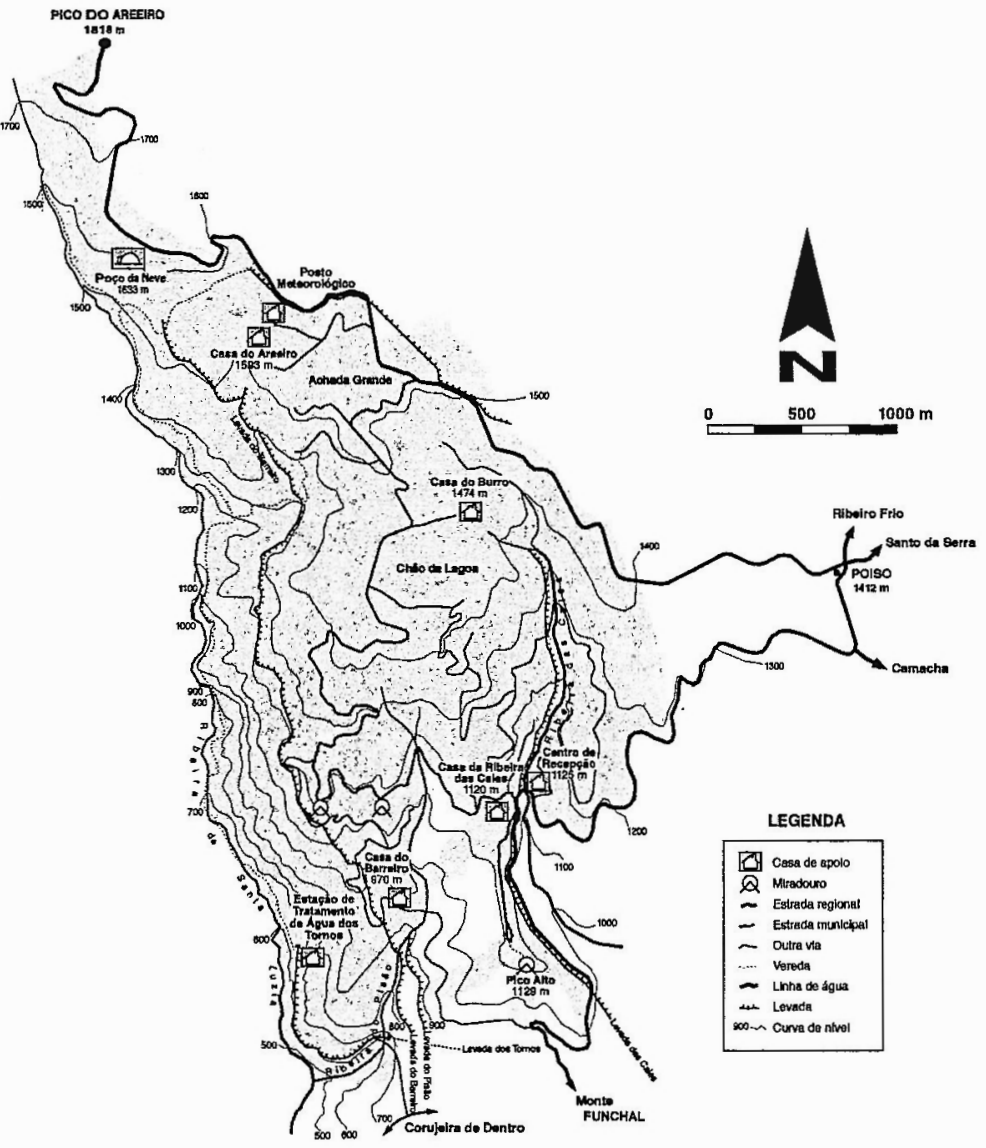

Mapa 2 - O Parque Ecológico do Funchal ocupa uma área de $10 \mathrm{Km}^{2}$ e estende-se desde os 500 metros de altitude até ao Pico do Areeiro $(1818 \mathrm{~m})$. 


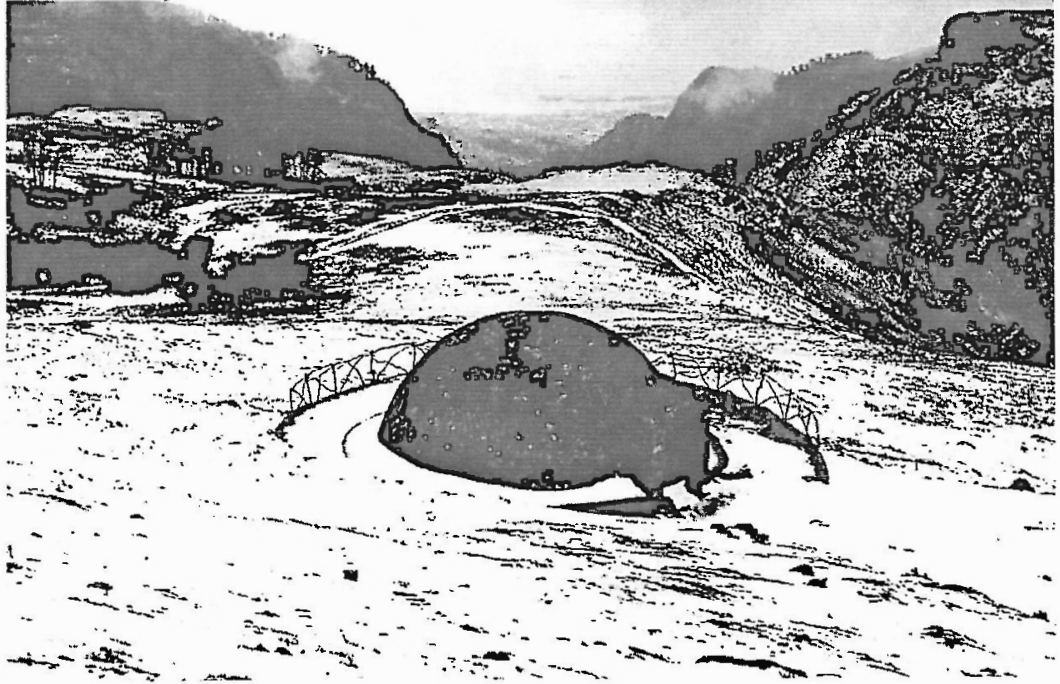

Foto 1 - O Poço da Neve é um dos símbolos do Parque Ecológico do Funchal (Foto: Sónia Dória) em comum, de gado suíno, caprino e ovino, sem o menor respeito pela lei das pastagens que proíbe a apascentação de gados em terrenos não cercados e sem a menor noção dos seus próprios interesses".

Em carta enviada ao Presidente da Câmara do Funchal, em 27 de Outubro de 1927, aquele técnico sugeria várias medidas necessárias para a implementação do plano de arborização, que estava a ultimar. A missiva terminava assim:

- "Transigindo com as conveniências dos pastores, principais inimigos das nossas serras que eles consideram suas, a Câmara torna-se, de algum modo, conivente no crime de liberdade de pastagem, proibida por lei, liberdade essa que tem reduzido as montanhas da Madeira ao estado de ruína em que actualmente se encontram".

Posteriormente, nos anos trinta e na década de quarenta, a Câmara comprou o Montado do Pisão e mais algumas pequenas parcelas, num total de aproximadamente 300 ha. Mesmo após as novas aquisições, esta vasta importante propriedade municipal continuou a ser conhecida por Montado do Barreiro.

Em 1946, quando a arborização do Montado do Barreiro já apresentava resultados interessantes, a Câmara publicou o "Plano de Arborização do Montado do Barreiro" elaborado pelo Eng. Abílio Barros e Sousa. Em boa hora a edilidade divulgou tal documento que revela uma visão extremamente inovadora para a época, como se pode deduzir do excerto que a seguir se reproduz:

"Ainda que outros motivos se não impusessem à nossa consideração ou militassem a favor de um maciço variegado ou matizado, o da representação e conservação das espécies arbóreas naturais da Ilha, algumas delas bastante preciosas pelos seus produtos lenhosos e óleos os justificaria, de sobra uma tal orientação. Das essências madeirenses consideradas espontâneas só as de pouco ou nulo valor comercial, tais como o loureiro, a urze e a uveira, são ainda comuns; as restantes, infelizmente, ou se acham quase extintas como sucede com o pau branco, o aderno, o sanguinho, o cedro da Madeira e o teixo, ou são já muito pouco frequentes como acontece com o til (cuja tendência é para desaparecer dada a prática perniciosa de se lhe arrancarem constantemente as suas folhas para alimentação de gado), o vinhático, o barbusano, a urze molar e a murta ...

Não ignora quem estas linhas escreve que a tendência da nossa silvicultura é para a constituição de povoamentos puros e em especial para os pinheirais e eucaliptais, por mais rendosos. Mas, pergunto eu, que beleza poderá ter qualquer daquelas duas matas?

Mesmo sob o ponto de vista do rendimento, quem me garante que o pinheiro, e maior força de razão o eucalipto, encontra condições de boa vegetação no montado do Barreiro até ao pico do Areeiro a $1810 \mathrm{~m}$ acima do nível do mar?"

O maciço arbóreo, misto de espécies indígenas e exóticas, idealizado por Abílio Barros de Sousa e acarinhado por várias gestões camarárias, infelizmente acabou por sofrer um forte revés.

A revolução de 25 de Abril de 1974 desencadeou no Funchal, como no resto do país, uma explosão de manifestações populares com inúmeras reivindicações. A Câmara tentou acudir às necessidades mais prementes no domínio da habitação, do fornecimento de água potável, no lançamento de redes de esgotos, na criação de novos caminhos em locais de dificílima acessibilidade, na melhoria do serviço de recolha de lixo. Enquanto isto o Montado do Barreiro era invadido por gado pertencente a indivíduos que, aproveitando o enfraquecimento transitório do poder autárquico, passaram a utilizar a vasta propriedade municipal da 
forma perniciosa que tanta reprovação merecera aquando daelaboração do notável Plano de Arborização cinco décadas antes.

Durante cerca de vinte anos o Montado do Barreiro foi palco dum intenso pastoreio de cabras e ovelhas e sofreu vários incêndios. Nas zonas mais baixas percorridas pelo fogo, os eucaliptos e as acácias expandiram-se livremente e tornaram-se infestantes. As rochas escalvadas passaram a dominar as terras altas, onde se localizam as cabeceiras da Ribeira de Santa Luzia e da Ribeira das Cales, afluente da Ribeira de João Gomes.

Em 1994, a nova gestão da Câmara do Funchal resolveu pôr um ponto final na ocupação abusiva dos terrenos municipais e definiu novos critérios de utilização mais consentâneos com os interesses da comunidade. No Plano Director Municipal, que então estava a ser elaborado, a vasta área montanhosa ficou consagrada como Unidade Especial de Gestão, ficando assim criado o suporte legal para a execução deste ambicioso projecto estruturante.

Nascia assim o PARQUE ECOLÓGICO DO FUNCHAL, que tem como objectivos:

- Promover a conservação da flora e fauna indígenas;

- Desenvolver um pólo de educação ambiental;

- Fomentar a investigação científica em cooperação com instituições nacionais e estrangeiras;

- Criar núcleos de recreio e lazer para os residentes e turistas.

Ainda em 1994, começou o processo de retirada das ovelhas e cabras que pastavam livremente na propriedade municipal, impedindo o crescimento das plantas e agravando a erosão. Embora fossem mais que evidentes os efeitos perniciosos do pastoreio intensivo e desordenado, a retirada do gado estendeuse até Outubro de 1995 devido à forte resistência dos donos dos animais, que alegavam ter direitos ancestrais. Após uma dura contenda, que terminou com o tribunal a dar razão às pretensões da Câmara, foi possível eliminar das terras do Parque Ecológico cerca de 1200 ovelhas e cabras. Só então foi possível iniciar o programa de repovoamento florestal, utilizando as mesmas espécies que ali existiam quando a Madeira começou a ser povoada na primeira metade do século $\mathrm{XV}$.

\section{Geologia e formas do relevo}

A crusta oceânica onde se localiza o arquipélago da Madeira tem cerca de 130 milhões de anos e pertence à placa tectónica africana. A Ilha da Madeira formou-se graças à ascensão de magma a partir dum hot spot (ponto quente) gerado numa pluma do Manto.

A construção duma ilha vulcânica assume três fases:-fase proto-insular, com o edifício a levantar-se desde o fundo oceânico até à superfície; fase emergente, com o edifício vulcânico a sair do oceano; fase subaérea, com o edifício vulcânico já emerso e com os aparelhos em actividade efusiva ou explosiva.

A subida do edifício vulcânico desde o fundo até à superfície do Atlântico foi muito lenta e as investigações mais recentes apontam para que tenha demorado mais de $100 \mathrm{Ma}$. No entanto, está longe de ser consensual a duração da fase subaérea da Ilha da Madeira. Para alguns geólogos teria começado há 24,1 milhões de anos (ALVES \& FORJAZ, 1991), enquanto as datações das rochas mais antigas feitas por outros apontam para os 5,2 milhões de anos (FERREIRA et al., 1988) ou apenas 2,5 milhões de anos (MATA, 1996).

A carta geológica (ZB YSZEWSKI et al., 1975) apresenta a Ilha da Madeira com uma estrutura caracterizada pela existência de cinco complexos vulcânicos principais (b1 , b2, b3, b4, b5). Segundo este modelo,

Foto 2 - Na cabeceira da

Ribeira de Santa Luzia são bem visíveis as escombreiras de gelifracção

(Foto: Raimundo Quintal)

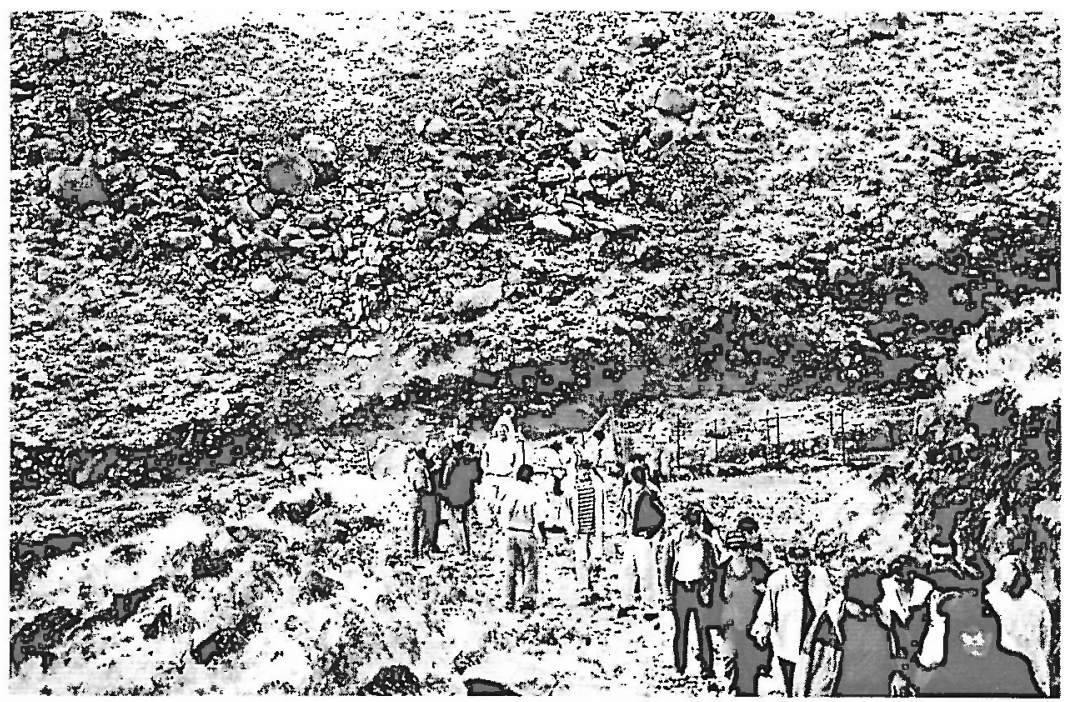




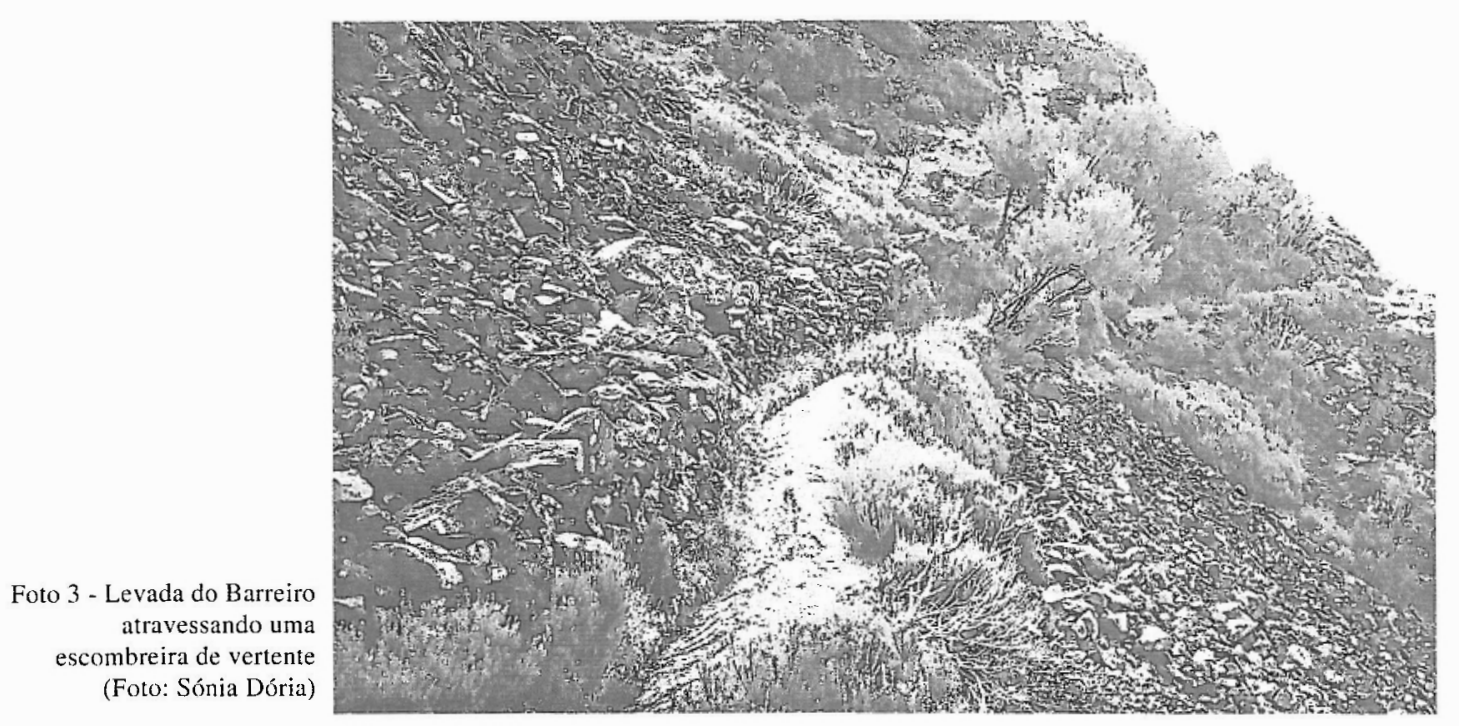

o último período de actividade vulcânica teria decorrido entre 500 mil e mais ou menos 200 mil anos.

Investigações mais recentes (MATA, 1996) apontam para a existência de mais um complexo(b6) constituído pelos pequenos cones vulcânicos periféricos, como por exemplo os picos da zona oeste do Funchal. Segundo esta tese a actividade vulcânica só cessou há cerca de 25.000 anos.

No Parque Ecológico ocorrem os quatro complexos vulcânicos mais antigos (Mapa 3). A parte mais alta, do Poço da Neve até ao Pico do Areeiro, pertence ao Complexo Vulcânico de Base (b1). Os afloramentos nesta área são constituídos por "materiais piroclásticos grosseiros com blocos angulosos, bombas vulcânicas, escórias, etc. Em muitos sítios da periferia existem intercalações basálticas provenientes de erupções de tipo fissural. Numerosos filões de rochas básicas recortam o complexo, apresentando orientações predominantes W-E e NW-SE" (in Nota Explicativa da Carta Geológica da Madeira).

Estas áreas altas, onde afloram as rochas mais antigas, estão expostas a temperaturas baixas que provocam a formação de geadas, e em quase todos os Invernos ocorrem quedas de neve e granizo. $\mathrm{O}$ gelo instala-se nas fissuras das rochas fracturando-as. Os blocos e os calhaus resultantes da crioclastia são facilmente movidos vertente abaixo pelas águas de escorrência por ocasião de fortes aguaceiros.

Apesar da Madeira ter ficado fora da zona abrangida pelas glaciações do Quaternário, as maiores altitudes da ilha ficaram sob a influência dum clima periglaciário, com temperaturas cerca de $8^{\circ} \mathrm{C}$ mais baixas que as actuais. Nesses períodos - o último (Wurm) teve o apogeu há 18 mil e terminou há cerca de 11 mil anos -os processos de crioclastia foram muito mais intensos do que na actualidade.
Como escreve Jean RISER (1999), "O princípio da erosão pelo gelo é simples. As rochas nunca são perfeitamente compactas, apresentam fendas e interstícios de todas as dimensões. A água da chuva ou da fusão da neve vai, pois, infiltrar-se progressivamente na superfície das rochas graças a todas estas asperezas. A água, ao gelar, aumenta o seu volume em 9 por cento e exerce uma pressão considerável sobre as paredes dos espaços vazios, dos interstícios e das fendas dos materiais rochosas, provocando a sua desagregação mecânica.

Quanto mais frequentes são as passagens da água do estado líquido ao estado sólido, tanto mais rápida será a desagregação; é aquilo a que se chama ciclos gelo-degelo, enquanto à fractura das rochas pelo gelo se dá o nome de gelifracção.

A acção do gelo associada à da água caracteriza o sistema de erosão dito periglaciário. O termo evoca uma localização em volta dos glaciares que nem sempre corresponde à realidade geográfica. Por exemplo, certas montanhas mediterrânicas actualmente desprovidas de glaciares sofrem apesar de tudo a influência do gelo.

(...) Estes mecanismos de gelo-degelo dos solos frequentemente argilosos explicam os fenómenos de convecção que deslocam os materiais dando forma, à superfície do solo, a grinaldas de cascalho, polígonos de calhaus, estrias de pedras e cascalho sobre os declives.

(...) Nas vertentes, sobretudo na montanha, a acção da gelifracção provoca a fragmentação das rochas das escarpas e a criação de montões de destroços. Nas rochas macias, os ciclos gelo-degelo combinados com a água da fusão do permafrost ou da neve favorecem os deslizamentos de terreno e as correntes de lama, manifestações de solifluxão. Nas montanhas semiáridas, a escorrência, associada à gelifracção 
Mapa 3 - Mapa geológico do Parque Ecológico do Funchal, elaborado a partir da Carta Geológica da Madeira da autoria de Zbyszewski et al. (1975) (Mapa criado por Eugénio Santos, Gabinete de Arte e Design da Câmara Municipal do Funchal.)

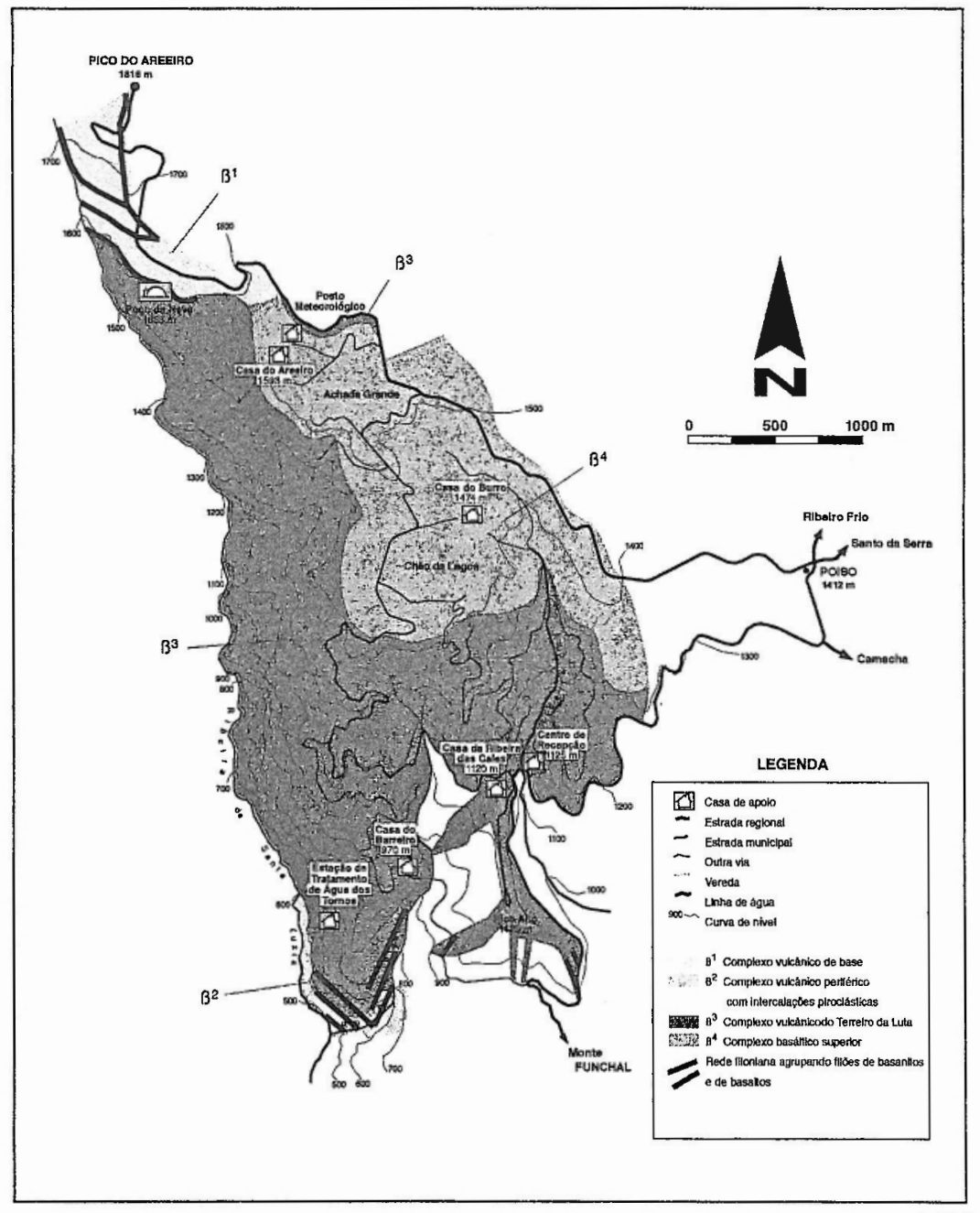

invernal em vertentes de rochas macias desprovidas de vegetação, desencadeia tais fenómenos".

Taludes de escombreiras de gelifracção, pináculos residuais de gelifracção, escoadas de solifluxão, grinaldas e círculos de pedras são marcas típicas da morfologia periglaciária ainda hoje bem visíveis entre o Chão da Lagoa e o Pico do Areeiro.

Os planaltos do Chão da Lagoa (Chão dos Balcões), da Achada Grande (onde se localiza o posto meteorológico) e do Chão do Areeiro fazem parte do Complexo Basáltico Superior (b4). Este complexo basáltico é "contemporâneo do complexo do Paul da Serra, apresentando as mesmas características litológicas". É constituído por "basaltos alcalinos com olivina, por basanitos e raras vezes por hawaiitos". Está recortado por "diversas chaminés e filões de rochas básicas de orientação NW-SE, nas duas extremidades do afloramento principal, e por outro de orientação SW-NE junto do Cabeço da Casa" (in Nota Explicativa da Carta Geológica da Madeira).
Para sul do Poço da Neve estende-se o Complexo Vulcânico do Terreiro da Luta (b3), que ocupa a maior parte do Parque. É constituído por "alternâncias de lavas em bancadas delgadas e de materiais piroclásticos com predominância das primeiras. Tratase, assim, de uma fase vulcânica mais efusiva que explosiva. As escoadas são constituídas por basaltos alcalinos com olivina, basanitoides, alguns hawaiitos e raros benmoreítos.

O conjunto forma uma cobertura em cima do maciço vulcânico primitivo do centro da ilha, apresentando-se sempre em posição bastante inclinada em volta dos centros vulcânicos principais da região central". Sobretudo na parte superior, observam-se "intercalações de tufos e de brechas avermelhadas" (in Nota Explicativa da CartaGeológicada Madeira).

O Pico dos Melros e o Pico Alto integram esta unidade geológica atravessada por uma rede de filões de basalto que afloram a sudeste do Pico Alto e entre este e o vale da Ribeira de Santa Luzia. Um destes 
filões, já fora do Parque, mas muito perto deste, continua a ser explorado para produção de brita.

No vale da Ribeira de Santa Luzia, na confluência com a Ribeira do Pisão e a oeste da Estação de Tratamento de Água dos Tornos, afloram os materiais do Complexo Vulcânico Periférico(b2). Neste complexo, "as lavas alternam com materiais piroclásticos vermelhos, amarelos ou castanhos por vezes bem estratificados. Estão recortados por diversos filões e por chaminés vulcânicas basálticas" (in Nota Explicativa da Carta Geológica da Madeira).

"A grande altitude média ( $90 \%$ da sua área está acima dos $500 \mathrm{~m}$ ) e elevada pluviosidade, aliada à coexistência de formações de diferente competência (piroclastos e lavas), conferem à Madeira um relevo vigorosíssimo caracterizado por uma grande imaturidade. Esta está bem expressa na rede hidrográfica que se caracteriza pela reduzida importância da erosão lateral das vertentes e pelos acentuados declives dos perfis longitudinais" (MATA, 1996).

A Ribeira de Santa Luzia é o curso de água mais notável do Parque Ecológico do Funchal e recebe a maior parte da água que se precipita nas terras altas. A sua bacia de recepção situa-se na zona de modelado periglaciário, onde abundam escombreiras de vertente, escoadas grosseiras de solifluxão e camadas de blocos de gelifracçãodespidas de vegetação. Se acrescentarmos a estas condições os fortes declives e mesmo algumas escarpas, então facilmente nos apercebemos das quantidades de calhaus e blocos rochosos que chegam ao fundo do vale por alturas dos violentos aguaceiros de Outono e Inverno. No sector intermédio desta ribeira, antes de entrar na zona urbana, há quedas de água de enorme beleza que podem ser apreciadas por quem percorrer a pé a Levada do Barreiro.
A Ribeira das Cales, afluente da Ribeira de João Gomes, é o segundo curso de água mais importante. Alimenta-se principalmente das águas que escorrem na parte oriental do Chão da Lagoa. O vale é menos encaixado que o da Ribeira de Santa Luzia, as vertentes apresentam uma maior cobertura arbórea, tem uma menor capacidade de transporte e as suas cheias são menos impetuosas.

\section{Caracterização climática}

$\mathrm{Na}$ área do Parque Ecológico só há registos das condiçōes atmosféricas no posto meteorológico do Areeiro, localizado no planalto da Achada Grande a 1610 metros de altitude. Para ultrapassarocontratempo da escassez de dados seleccionámos os valores registados no Areeiro e na estação do Funchal, o que permite conhecer por extrapolação os valores de temperatura e precipitação nas diferentes zonas do Parque (Quadro I).

A temperatura média anual na estação do Areeiro $\left(9,1^{\circ} \mathrm{C}\right)$ é inferior a metade da observada no Funchal $\left(18,7^{\circ} \mathrm{C}\right)$. Feitas as contas conclui-se facilmente que, por cada 100 metros de altitude, a temperatura baixa $0,6^{\circ} \mathrm{C}$. Logo na parte mais baixa do Parque, aos 500 metros de altitude, a temperatura média do ano deve rondar os $15,7^{\circ} \mathrm{C}$.

Com o crescimento da altitude também aumenta muito significativamente a precipitação. Em cada 100 metros que se sobe a pluviosidade aumenta, em média, $148 \mathrm{~mm}$. No Funchal, num ano, em média chove $641 \mathrm{~mm}$, enquanto o posto do Areeiro regista uma precipitação média total de $2939 \mathrm{~mm}$. Além desta enorme diferença, registe-se o facto de no Areeiro

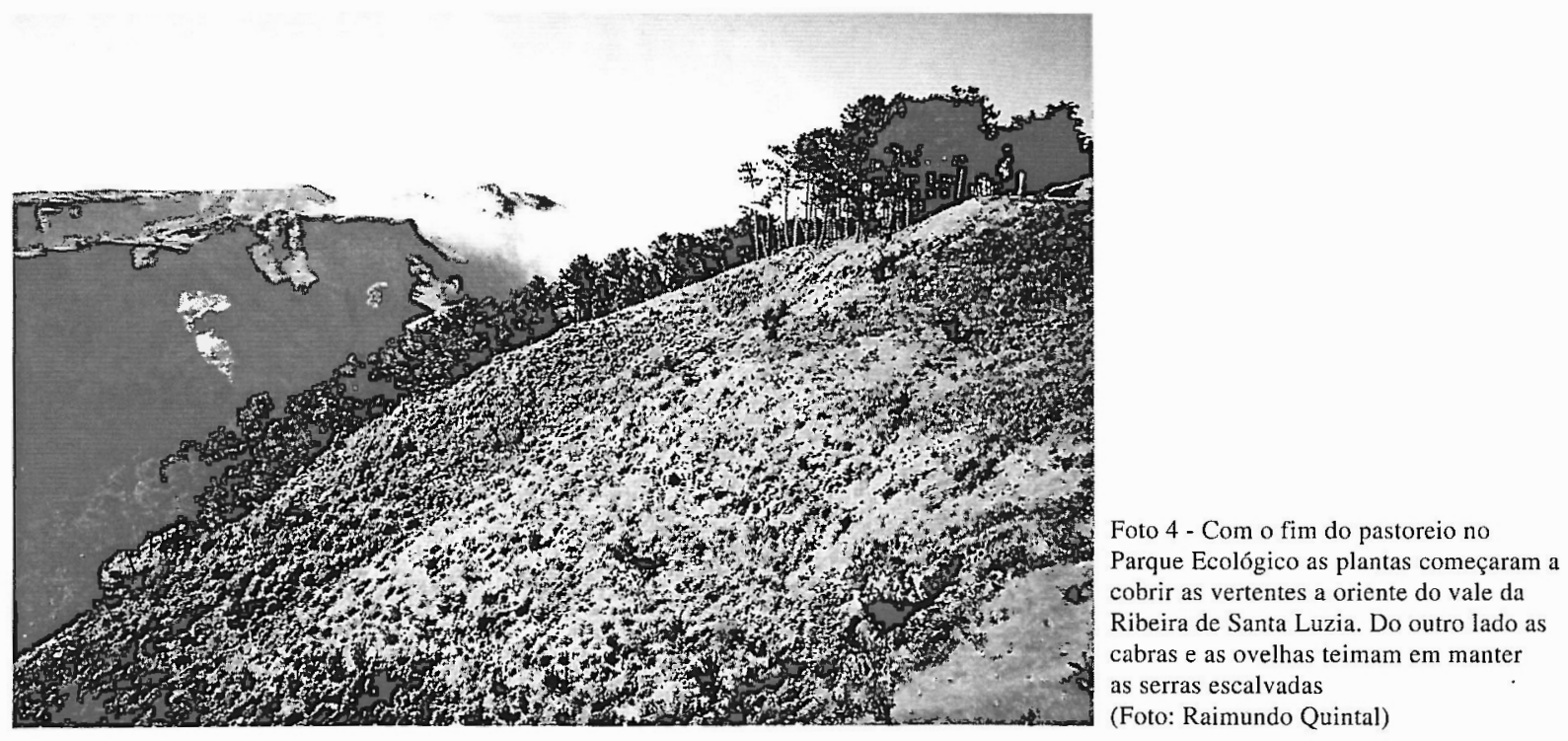




\begin{tabular}{|l|c|c|c|c|c|c|}
\hline \multirow{5}{*}{ MESES } & \multicolumn{3}{|c|}{$\begin{array}{c}\text { FUNCHAL-58 } \mathrm{m} \\
(1961-1990)\end{array}$} & \multicolumn{3}{c|}{$\begin{array}{c}\text { AREEIRO - 1610 m } \\
(1961-1990)\end{array}$} \\
\cline { 2 - 7 } & $\begin{array}{c}\text { T. Média } \\
{ }^{\circ} \mathrm{C}\end{array}$ & $\begin{array}{c}\text { Precipitação } \\
\text { média total } \\
(\mathrm{mm})\end{array}$ & $\begin{array}{c}\text { Precipitação } \\
\text { máxima díria } \\
(\mathrm{mm})\end{array}$ & $\begin{array}{c}\text { T. Média } \\
{ }^{\circ} \mathrm{C}\end{array}$ & $\begin{array}{c}\text { Precipitação } \\
\text { média total } \\
\text { (mm) }\end{array}$ & $\begin{array}{c}\text { Precipitação } \\
\text { máxima diária } \\
(\text { mm })\end{array}$ \\
\hline Janeiro & 16,1 & 102,7 & 90,2 & 5,5 & 437,8 & 210,2 \\
Fevereiro & 15,9 & 87,2 & 63,3 & 5,6 & 378,0 & 240,2 \\
Março & 16,3 & 63,6 & 48,2 & 6,2 & 304,0 & 226,8 \\
Abril & 16,5 & 38,9 & 41,7 & 6,1 & 211,6 & 156,2 \\
Maio & 17,7 & 18,9 & 71,4 & 8,2 & 16,6 & 149,5 \\
Junho & 19,4 & 11,9 & 57,8 & 11,0 & 69,9 & 282,2 \\
Julho & 21,1 & 2,5 & 14,1 & 14,6 & 13,2 & 22,9 \\
Agosto & 22,3 & 3,1 & 12,0 & 14,8 & 33,5 & 72,0 \\
Setembro & 22,3 & 36,7 & 97,7 & 12,8 & 169,7 & 215,3 \\
Outubro & 20,9 & 75,0 & 91,7 & 10,3 & 307,4 & 201.7 \\
Novembro & 18,8 & 100,8 & 76,6 & 7,8 & 449,9 & 204,8 \\
Dezembro & 16,9 & 99,9 & 84,9 & 6,0 & 447,7 & 204,2 \\
\hline ANO & 18,7 & 641,2 & 97,7 & 9,1 & 2939,3 & 282,2 \\
\hline
\end{tabular}

Fonte: Instituto de Meteorologia - Delegação Regional da Madeira

cair neve e granizo nos meses mais frios. No Inverno e especialmente durante a noite são frequentes as temperaturas negativas e a formação de geada.

A altitude provoca significativas diferenças de temperatura e precipitação, mas aos diferentes níveis chove sempre menos nos meses mais quentes. Para M. GAUSSEN um mês é considerado seco quando a precipitação total em mm é inferior ao dobro do valor da temperatura em ${ }^{\circ} \mathrm{C}(\mathrm{P}<2 \mathrm{~T})$.

A aplicação desta fórmula permite concluir que no Funchal a estação seca tem uma duração de 5 meses (Maio - Setembro), enquanto no Areeiro só dura um mês (Julho).

Odecréscimo da temperatura, o aumento da precipitação e o consequente encurtamento da estação seca com a altitude reflectem-se na distribuição das formações vegetais.
Mas se os valores médios fornecem importantes indicações para a compreensão dos andares fitoclimáticos, os valores extremos de temperatura, as precipitações excepcionalmente fortes, os ventos violentos e os períodos de seca anormal podem causar impactos significativos no coberto vegetal e provocar alterações na morfologia do relevo.

Os valores máximos de precipitação diária no Pico do Areeiro no período em análise ultrapassaram várias vezes os $200 \mathrm{~mm}$, atingindo o valor absoluto de 282,2 $\mathrm{mm}$. Este indicador revela que, para além de chover muito nas grandes altitudes da cordilheira central, a precipitação ocorre de forma concentrada e em poucas horas pode causar forte erosão se os solos não estiverem cobertos de vegetação.

Nesses momentos de violentos aguaceiros os materiais soltos das escombreiras são carreados para

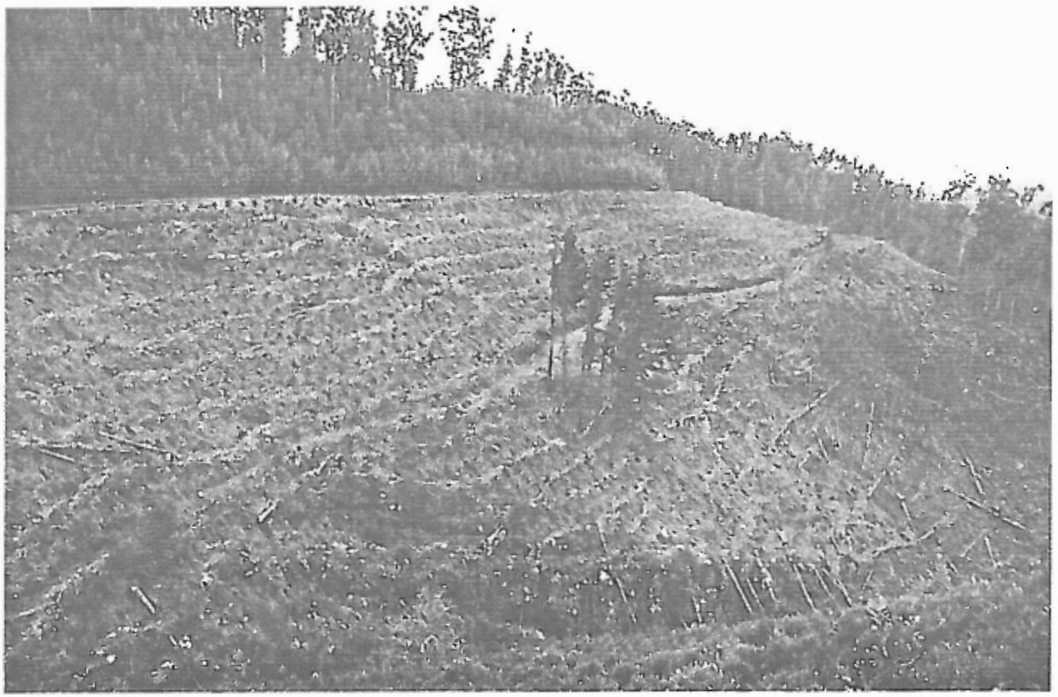

Fotos 5 - Os eucaliptos são cortados, os troncos colocados segundo as curvas de nível para evitar a erosão e nos socalcos são plantadas árvores indígenas. (Fotos: Eugénio Santos) 
Foto 6 - Nas zonas mais altas, para cima dos 1300 metros, as urzes começam a prender os calhaus e blocos rochosos nas vertentes da bacia de recepção da Ribeira de Santa Luzia.

(Foto: Sónia Dória)

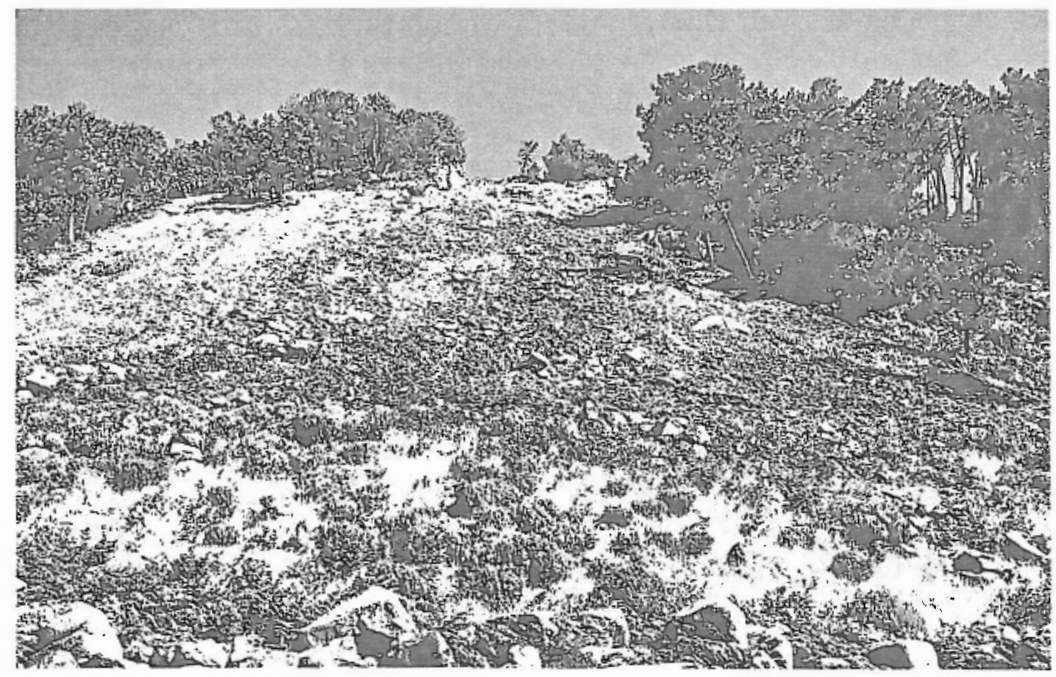

a Ribeira de Santa Luzia e transportados rapidamente até à baixa do Funchal. Algumas dessas cheias provocaram mortos e grande destruição na cidade. A mais mortífera foi a 9 de Outubro de 1803 e a última ocorreu a 29 de Outubro de 1993.

\section{Património natural e cultural}

O logotipo do Parque Ecológico do Funchal integra três elementos, que representam o património florístico (Sorveira), faunístico (Patagarro) e cultural (Poço da Neve).

\subsection{Flora}

A Sorveira ou Tramazeira (Sorbus maderensis) é uma pequena árvore de folha caduca, com flores brancas no Verão e cachos de frutos vermelhos muito vistosos no princípio do Outono. A Sorveira é endémica da Madeira e os exemplares adultos não chegam a uma centena. Depois de muitos anos vítima do apetite das cabras e ovelhas, é agora objecto dum rigoroso plano de conservação.

As sorveiras vivem integradas nas formações arbustivas que cobrem o Pico dos Melros e a escarpa a norte do Chão do Areeiro, a altitudes compreendidas entre os 1400 e os 1600 metros. As urzes (Erica scoparia ssp. maderinicola; Erica arborea) e a Uveira (Vaccinium padifolium) são as espécies predominantes destas associações. Nelas também vive o perado (llexperado ssp.perado), uma urze endémica subarbustiva (Erica maderensis), a estreleira (Argyranthemun pinnatifidum ssp. montanum), o massaroco (Echium candicans), a ameixieira de espinho (Berberis made- rensis), o alecrim da serra (Thymus caespititius) e plantas herbáceas como o ranúnculo (Ranunculus cortusifolius), a saxífraga (Saxifraga maderensis), a orquídea da rocha (Orchis scopulorum), a erva arroz (Sedum farinosum), ou a leituga (Tolpis macrorhiza).

A espécie de maior porte desta formação é sem dúvida o loureiro (Laurus azorica) que é pouco frequente e não atinge o porte que ostenta na Laurissilva, apresentando folhas mais pequenas pois lá em cima os ventos e as baixas temperaturas constituem factores limitantes ao seu desenvolvimento.

As outras três lauráceas indígenas não resistem aos rigores atmosféricos das grandes altitudes, aparecendo mais abaixo em terrenos que foram de Laurissilva antes da intensa exploração das madeiras e lenhas. Embora sem exemplares de grande porte e sem a densidade que caracteriza a floresta que cobre extensas áreas do norte da ilha, no Parque Ecológico, em sítios que resistiram às acácias e eucaliptos invasores, há tis (Ocotea foetens), vinháticos (Persea indica) e barbusanos (Apollonias barbujana).

Para além das quatro lauráceas existem dispersas pelo Parque outras árvores de menor porte que são vestígios da floresta primitiva. São, por exemplo, o pau branco (Picconia excelsa), o folhado (Clethra arborea), o aderno (Heberdenia excelsa), o cedro da Madeira (Juniperuscedrus), o seixo (Salixcanariensis), o sanguinho (Rhamnus glandulosa), o marmulano (Sideroxylon marmulano) e os azevinhos indígenas (Ilex perado ssp. perado; Ilex canariensis).

Nas zonas mais baixas do Parque, próximas dos 600 metros de altitude, como por exemplo nas escarpas atravessadas pela Levada dos Tornos, é possível encontrar plantas típicas das formações que marcam a transição entre a vegetação xerófila do litoral e a floresta higrófila. 
Dependuradas nas rochas, com as raízes afincadas nas fissuras do basalto ou nas fendas dos piroclastos, prosperam faias das ilhas (Myrica faya), marmulanos (Sideroxylon marmulano), globulárias (Globularia salicina), hipericãos ou malfuradas (Hypericum inodorum; Hypericum glandulosum; Hypericum canariense var. floribundum), piornos ( Genista tenera; Teline maderensis), murtas (Myrtus communis), ensaiões (Aeonium glandulosum; Aeonium glutinosum), abrotônas (Teucrium betonicum), cabreiras (Phyllis nobla), leitugas (Sonchus pinnatus) e serralhas da rocha (Sonchus fruticosus).

Mas a riqueza da flora não se fica por aqui. São muitos os arbustos, plantas herbáceas e fetos que povoam os recantos onde não chegou a acção predatória do gado, estando inventariadas cerca de sete dezenas de plantas indígenas, sendo muitas delas exclusivas da Madeira.

Além do conjunto das espécies indígenas que constituem a flora, a vegetação do Parque Ecológico do Funchal integra muitas outras plantas exóticas. Umas foram introduzidas intencionalmente nas plantações iniciadas nos finais da década de vinte, outras fixaram-se graças a sementes e esporos transportados pelo vento, pelos pássaros e insectos.

O pinheiro bravo (Pinus pinaster) é a conífera mais abundante, formando manchas importantes abaixo do Chão da Lagoa. Embora menos frequentes, outros três pinheiros formam povoamentos com algum sgnificado: - Pinus radiat; Pinus sivestri; Pinus strobus.

Do conjunto das gimnospérmicas destacam-se pelo númeroelevado, além dos pinheiros, duas espécies vulgarmente conhecidas por cedros (Cupressus lusitanica; Cupressus macrocarpa) e a pseudotsuga (Pseudotsuga menziesii). O cipreste do Oregão
(Chamaecyparis lawsoniana), a sequóia (Sequoia sempervirens) e a criptoméria (Cryptomeria japonica) têm uma representação menos significativa.

Das folhosas exóticas a que ocupa maiores áreas é, sem dúvida, o Eucalyptus globulus. Esta árvore oriunda da Austrália, introduzida na Madeira na segunda metade do século passado com o objectivo de produzir madeira e lenha, é hoje infestante. Eucalyptus citriodora, Eucalyptus obliqua, Eucalyptus regnans, Eucalyptus viminalis são outros eucaliptos australianos que vivem no Parque Ecológico mas sem a capacidade expansiva do seu congénere.

Igualmente da Austrália vieram as diferentes espécies de acácias que povoam algumas vertentes abaixo dos 1300 metros: - Acacia melanoxylon, Acacia dealbata, Acacia mearnsii, Acacia falcata, Acacia floribunda, Acacia verticilata, Acacia elata, Acacia nerifolia. Dum modo geral têm grande capacidade para se expandirem, especialmente nas zonas que foram atacadas pelos fogos, mas a $A$. melanoxylon e a A. mearnsii são as mais agressivas para as espécies indígenas, revelando-se bastante difícil a sua erradicação.

Outra espécie com capacidade invasora é o Acer pseudoplatanus, natural da Europa e do sudoeste da Ásia, que surge na área a oeste da casa do Barreiro.

As azinheiras (Quercus rotundifolia) e os castanheiros (Castanea sativa) formam bonitas manchas na vertente oriental da ribeira de Santa Luzia, onde também prosperam nogueiras ( Juglans regia; Juglans nigra).

Gleditschia triacantos, Cinnamomum camphora, Quercus robur, Fagus sylvatica, Fraxinus excelsior, Liglistrum japonicum, são outras árvores exóticas que podem ser observadas no Parque Ecológico do Funchal.

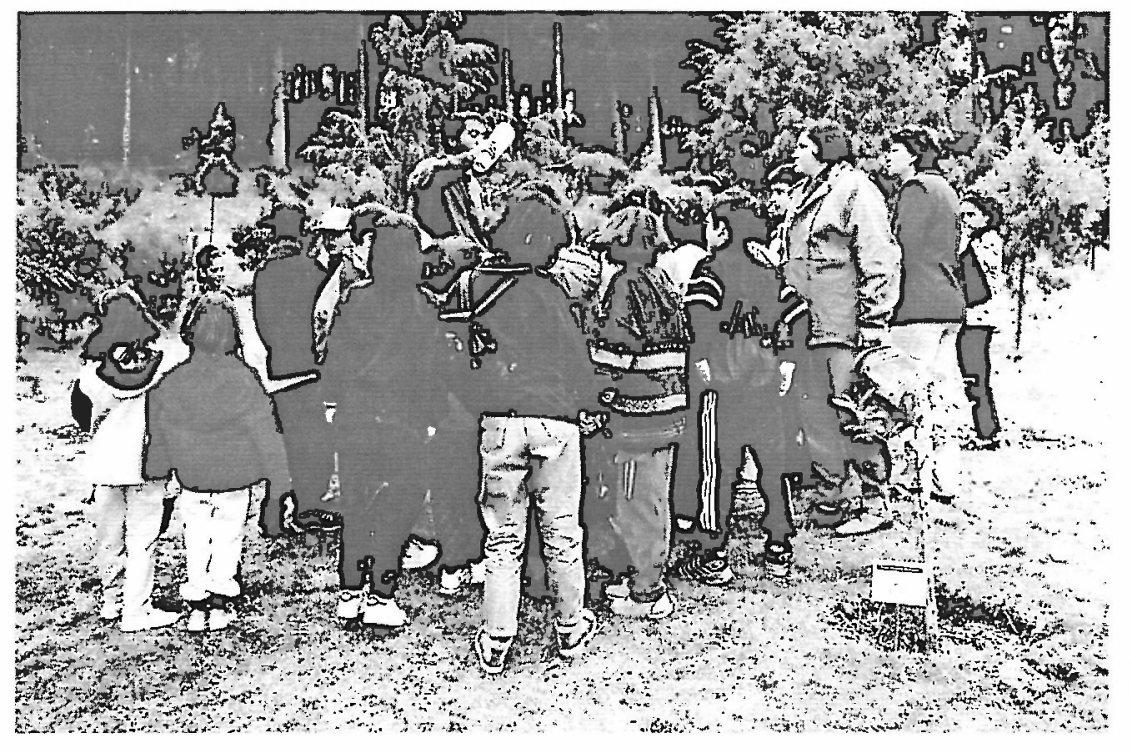

Foto 7 - A educação ambiental é um dos objectivos prioritários do Parque Ecológico do Funchal (Foto: Sónia Dória) 


\subsection{Fauna}

OPatagarro (Puffinus puffinus) é uma ave marinha que chega à Madeira em Janeiro e parte em Agosto. Nidifica no Parque Ecológico, mais propriamente nas vertentes escarpadas e húmidas da Ribeira de Santa Luzia próximas da Estação de Tratamento de Água dos Tornos. Depois de cerca de 50 dias de incubação, a eclosão tem lugar em Maio, seguindo-se mais 4 a 6 semanas até as jovens aves saírem dos ninhos instalados no fundo das tocas.

Durante muitos anos os patagarros foram alvo de grande predação por ratos e gatos. Com a criação do ParqueEcológico começou um projecto de conservação que, entre outras acções, integra o trabalho de colocação de raticida nas áreas onde se localizam as tocas de nidificação. Trata-se dum trabalho muito difícil, que só tem sido possível com a colaboração de sócios da Associaçãode Amigos do Parque, dos seus funcionários e dos militares do RG3. Graças ao esforço e dedicação de todos os que têm participado no projecto, os juvenis têm conseguido executar o seu primeiro voo em direcção ao mar.

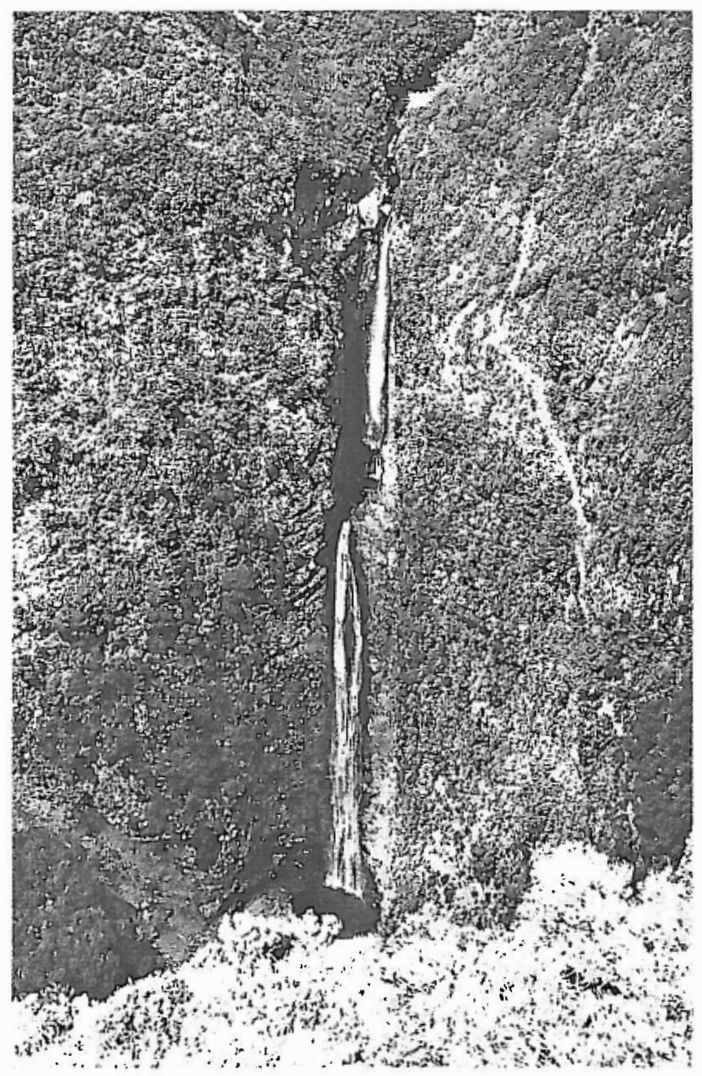

Foto 8 - Quedas de água na Ribeira de Santa Luzia, próximo da Estação de Tratamento de Água dos Tornos. (Foto: Raimundo Quintal)
O Patagarro é uma das 54 aves registadas no Parque Ecológico do Funchal desde 1994. Das nidificantes a maior é a Manta (Buteo buteo harterti), uma imponente rapinácea, e a mais pequena o Bisbis (Regulus ignicapillus madereinsis), que se alimenta de insectos e não ultrapassa os $9 \mathrm{~cm}$ de comprimento.

Quem também nidifica nesta área protegida é o Pombo Trocaz (Columba trocaz), que é uma das duas aves endémicas da Madeira. Este pombo grande, com patas avermelhadas e uma faixa clara na cauda, tem particular predilecção pelos frutos das lauráceas mas também gosta das bolotas das azinheiras.

No arquipélago da Madeira estão identificadas 15 espécies de borboletas, sendo duas endémicas, e mais de 300 espécies de besouros, dos quais cerca de 30 são exclusivos destas ilhas. No entanto, muito ainda há para conhecer a propósito destes insectos. Em Maio de 1997 começou no Parque Ecológico do Funchal um trabalho de campo com o objectivo de inventariar e descrever os lepidópteros ali residentes. O estudo coordenado pelo biólogo Andrew Dawfon, do Museu de História Natural de Londres, decorreu até Julho de 1998, estando a ser preparado um guia, que será um excelente instrumento para a educação ambiental dos visitantes do Parque.

No Mundo existem entre 900 e 1000 espécies de morcegos. Em Portugal estão identificadas 24 espécies e na Madeira estão registadas 5 espécies. Três destas espécies de mamíferos voadores foram observadas e fotografadas no Parque Ecológico do Funchal, no decurso duma investigação dirigida pela bióloga Linda Barnett, da universidade inglesa de Coventry. Um desses morcegos (Pipistrellus maderensis) vive apenas na Madeira e nalgumas ilhas das Canárias.

\subsection{Património cultural}

Construído por pedreiros madeirenses a expensas dum negociante de sorvetes italiano, o Poço da Neve foi utilizado desde 1813 até ao início do século XX. Feito com lascas de basalto, tem a forma de "igloo" e possui um reservatório escavado no solo com 8 metros de profundidade. Depois de quase cem anos de abandono foi recuperado e enchido novamente em Janeiro de 1999 com o intuito de mostrar às gerações actuais quão difícil era arranjar gelo antes da existência das câmaras frigoríficas.

O Poço da Neve é um dos elementos emblemáticos do património cultural do Parque Ecológico do Funchal. As levadas, as obras de captação das nascentes dos Tornos e de muitas outras existentes no antigo Montado do Barreiro, e a antiga Estação de Tratamento de Água dos Tornos completam um património edificado em condições orográficas muito difíceis, totalmente ligado ao transporte da água da montanha para a cidade. 
Quatro levadas sulcam as terras do Parque. Três são muito antigas e continuam a levar a água das ribeiras de Santa Luzia, Cales e Pisão para as terras agrícolas das freguesias do Monte, Imaculado Coração de Maria e Santa Luzia.

A levada das Cales foi edificada por iniciativa de Charles Murray, consul inglês e dono duma vasta propriedade na freguesia do Monte. A água começou a correr em 1784, como atesta uma lápide existente perto do leito da ribeira das Cales. As levadas do Barreiro e do Pisão, igualmente talhadas na rocha, pelas suas características devem ser tão ou mais antigas quea das Cales, mas não dispomos de indicações quanto às datas das suas construções.

A levada dos Tornos é muito mais recente. Os trabalhos iniciaram-se em 1958 e só ficaram concluídos em Setembro de 1966. A água transportada do norte da ilha, chega à margem esquerda da ribeira de Santa Luzia através dum túnel de 5100 metros. Junto à embocadura sul funcionou durante mais de trinta anos a Estação de Tratamento dos Tornos, que constituiu a principal fonte de abastecimento de água potável do concelho do Funchal. A ETA foi desactivada em Maio de 2000 e agora funciona como pólo de educação ambiental especialmente vocacionado para a divulgação da epopeia da conquista da água na Madeira.

Mesmo após a entrada em funcionamento da nova ETA, no sítio da Alegria em São Roque, a água continua a correr no troço sul da Levada dos Tornos para o regadio das terras agrícolas da zona leste do Funchal e de parte significativa do concelho de Santa Cruz.

Em 1898 a Câmara iniciou os trabalhos de captação de água das nascentes do Montado do Barreiro, localizadas nas rochas da vertente oriental do vale da ribeira de Santa Luzia, visando o abastecimento duma nova rede de fontanários públicos. Construídos tanques de decantação, câmaras de perda de carga e lançadas as condutas, o sistema só começou a funcionar em 1912, após uma longa contenda com outras partes interessadas na utilização das águas da bacia hidrográfica da Ribeira de Santa Luzia.

Porque as nascentes exploradas já não eram suficientes para as necessidades do concelho, em 1918 a Câmara adquiriu, por expropriação, o Montado do Barreiro "a diversos indivíduos seus proprietários, com o fim especial de proceder à exploração de águas destinadas ao abastecimento da cidade do Funchal e seus arredores" (A. B. SOUSA, 1946).

Em 1927 começou a plantação das árvores previstas no "Plano de Arborização do Montado do Barreiro". Tratou-se dum plano revolucionário em Portugal, pois pela primeira vez foi realizada uma grande obra de florestação no nosso país com o objectivo principal de aumentar a produção de água.
Com a entrada em funcionamento da Estação dos Tornos na década de 60, algumas das nascentes ficaram abandonadas mas outras ainda se mantêm operacionais, fornecendo água para as zonas altas da freguesia do Monte.

Recentemente foram recuperadas as levadas das Cales e do Barreiro, e as antigas veredas entre a casa do Barreiro, as nascentes dos Tornos Altos e a Levada dos Tornos. A recuperação dessas peças do património cultural, abriu caminho à realização de percursos pedestres de descoberta e conhecimento das formações geológicas, da flora, da fauna e da arriscada obra de captação de água potável.

\section{Medidas para reduzir os riscos de incêndio e de cheias catastróficas}

$\mathrm{O}$ projecto que esteve na origem do Parque Ecológico tinha como ideia central o retorno das espécies indígenas da flora e da fauna ao seu habitat, o que só seria possível após a expulsão dos animais e plantas que impediam o sucesso da operação. A estratégia adoptada tinha e tem como objectivo prioritário a criação duma nova ordem ecológica assente na biodiversidade.

O conhecimento da geografia física foi essencial para organizar a logística, criar bases de apoio às espécies que resistiram à predação e à invasão, e alargar a sua área de distribuição. Foram criados dois viveiros de plantas indígenas e recuperadas três casas para receber grupos interessados em participar nas actividades de educação ambiental e nos trabalhos de florestação.

No Inverno de 1995, já só com um rebanho ordenado de 250 ovelhas e com toda a propriedade vedada, começou a plantação de árvores e arbustos indígenas.

Em 1996 foram cortados os eucaliptos numa área de 50 hectares, que foi totalmente plantada com espécies da flora macaronésica.

Uma operação desta envergadura em terrenos de forte declive é complexa e exige muitos cuidados, sob pena de poder causar danos ambientais eeconómicos importantes. De forma a diminuir os riscos de escorregamento de solos em momentos de aguaceiros fortes, os troncose ramos das árvores cortadas foram estendidos no solo segundo as curvas de nível. Assim, a erosão é refreada pela sucessão de barreiras enquanto a nova associação não forma um coberto suficientemente denso.

Para dificultar a germinação e a rebentação dos eucaliptos iniciou-se a sementeira de giesta (Cytisus scoparius) e piorno (Teline maderensis), dois arbustos da família das Fabáceas de crescimento rápido que, para além de enriquecerem o solo em nitrato, provocam sombra aos eucaliptos, que gostam de luz forte, e 


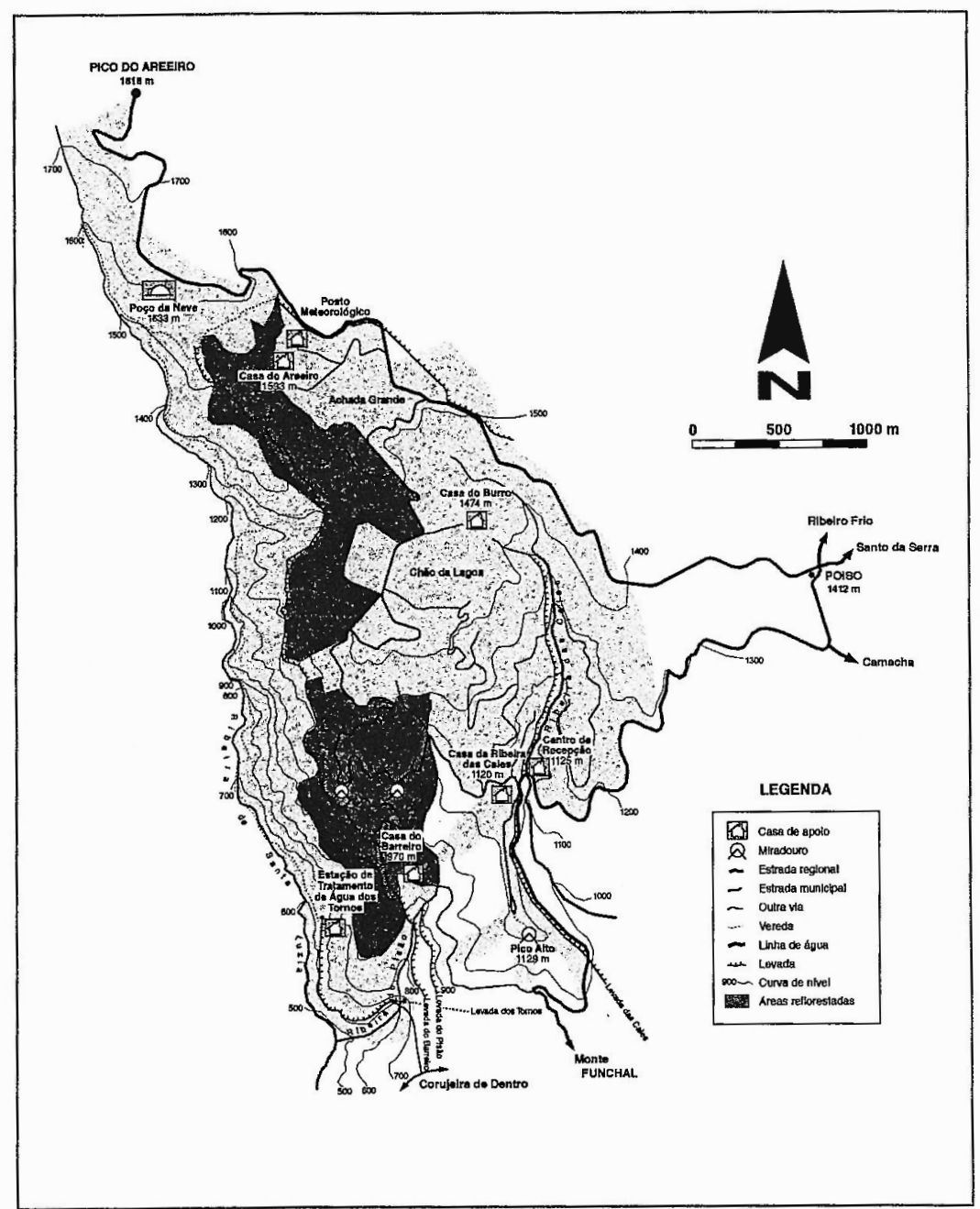

Mapa 4 - Áreas onde estão a ser substituídos eucaliptos e acácias por associações de plantas indígenas. (Mapa criado por Eugénio Santos, Gabinete de Arte e Design da Cânara Municipal do Funchal.)

favorecem o desenvolvimento das jovens árvores indígenas, que nutrem preferência por ambientes abrigados da insolação directa.

Em 1997 continuou a erradicação de eucaliptos e acácias em mais 25 hectares, seguida da introdução de espécies autóctones.

Em 1998 e 1999 foi feita nova limpeza dos jovens eucaliptos e acácias nas áreas intervencionadas nos anos anteriores, e introduzidas mais plantas indígenas em substituição das que morreram (Mapa 4).

No Outono de 1999 começaram os trabalhos de limpeza de 96 hectares de pinhal degradado. Os pinheiros mortos ou em mau estado, pertencentes especialmente às espécies Pinus pinaster e Pinus radiata, foram cortados e estão a ser substituídos por árvores e arbustos autóctones com o objectivo de criar uma floresta mista.

No biénio 2000-2001 será limpa a última área de eucaliptos num total de 86 hectares, seguindo-se a sua substituição por uma grande variedade de espécies madeirenses. As plantas a introduzir já estão a crescer nos viveiros do Parque, tendo uma parte importante sido fornecida pela Direcção Regional de Florestas e pela Fundação Berardo.

Na zona mais alta, onde os eucaliptos e as acácias não conseguiram vencer a oposição do frio, e as cabras e ovelhas foram retiradas, as urzes (Erica arborea, Erica scoparia ssp. maderinicola e Erica maderensis) crescem espontaneamente aos milhares. Aí a estratégia adoptada é a de complementar a autorregeneração. Entre as urzes estão a ser plantadas uveiras da serra (Vaccinium padifolium), perados (llexperado ssp.perado), loureiros (Laurus azorica), cedros da Madeira (Juniperus cedrus), sorveiras (Sorbusmaderensis), ameixieiras-de-espinho(Berberis maderensis), piornos (Genista tenera), estreleiras (Argyranthemum pinnatifidum ssp. montanum) e massarocos (Echium candicans).

Esta formação vegetal começa a desempenhar uma função extremamente importante na redução 
dos riscos de cheia, prendendo os solos, os calhaus e os blocos rochosos das escombreiras de vertentes nas bacias de recepção das ribeiras de Santa Luzia e das Cales.

Cerca de 160 mil árvores e arbustos indígenas, pertencentes a mais de duas dezenas de espécies, foram plantadas, nos últimos quatro anos, nas vertentes escalvadas e onde antes apenas havia eucaliptos ou acácias.

Está a operar-se a substituição das matas monoculturais por associções vegetais indígenas que, num horizonte de quinze anos, formarão coberturas densas e estratificadas, capazes de suster os solos. A floresta que está a despontar terá uma enorme importância na recarga dos lençóis freáticos porque, além de contribuir para o aumento das infiltrações e para a diminuição daescorrência quando chove, irá gerar forte precipitação de contacto à passagem dos nevoeiros.

Enquanto não existir uma floresta com um sub-bosque sempre verde, há o risco das gramíneas, que crescem entre as árvores dispersas, ficarem muito secas no Verão e arderem facilmente. Com o objectivo de evitar incêndios e matá-los à nascença em caso de ocorrência, uma equipa dos Bombeiros Municipais mantém-se em alerta permanente no Parque desde o primeiro dia de Maio até ao fím de Outubro.

Para melhorar a eficácia da acção dos bombeiros foram abertos caminhos florestais, que funcionam igualmente como corta fogo, e construídos reservatórios de água para abastecer os autotanques, não só em caso de incêndio mas também para regar as novas árvores durante o Verão.

Todo este esforço insere-se num projecto mais amplo da Câmara do Funchal visando a prevenção de fogos florestais, que integra um posto de vigilância permanente no Pico do Buxo, circuitos de reconhecimento, com motas e carros todo o terreno, nas áreas florestais mais atreitas à propagação do lume e a aplicação rigorosa do Regulamento Municipal sobre Prática de Fogueiras e Queimadas.

Este Regulamento em vigor desde 1996 proíbe as queimadas entre 1 de Maio e 31 de Outubro. Mesmo nos restantes meses as queimadas só podem ser realizadas entre as 8 e as 20 horas e mediante uma licença solicitada aos Bombeiros Municipais, que nos casos de maior risco deslocam um piquete para o local sem quaisquer encargos para o requerente. As infracções são punidas com as coimas previstas no art. $17^{\circ}$ do Dec. Lei $244 / 95$ de 14 de Setembro. Para pessoas singulares variam entre $750 \$ 00$ e $750.000 \$ 00$; para pessoas colectivas atingem $9.000 .000 \$ 00$.

A entrada em vigor do regulamento e a adopção das medidas preventivas provocaram um decréscimo de $87 \%$ no número de horas de actuação dos Bombeiros Municipais no combate a fogos florestais. A área de floresta ardida no concelho do Funchal, no período 97/99, diminuiu $57 \%$ em relação ao período 94/96.
No Parque Ecológico o último incêndio ocorreu em Setembro de 1994, quando decorria o conturbado processo de retirada do gado. Em Março de 1998, durante um período de vento de leste, muito quente e seco, houve uma tentativa de fogo posto mas os bombeiros debelaram-no com rapidez.

Os bons resultados obtidos pela aplicação do regulamento municipal induziram a feitura dum decreto regional em 1998.

Para além de realizarem circuitos de vigilância os bombeiros ajudam na rega das pequenas plantas durante o Verão, o que em muito contribui para a elevada taxa de sucesso das plantações e para acelerar o ritmo de crescimento.

A luta contra a desertificação e a erosão tem contado com o trabalho de muitos grupos de voluntários e com a colaboração dos militares do RG3. Da continuação das acções de repovoamento vegetal das serras escalvadas entre os vales das ribeiras de Santa Luzia e João Gomes, resultará uma paisagem de grande qualidade, rica em espécies indígenas, menos atreita aos fogos que os pinhais e eucaliptais, com muito maior capacidade de produção de água e fundamental para a segurança da cidade.

A biodiversidade está de volta no Parque Ecológico, os fogos florestais deverão diminuir e a cidade do Funchal ficará menos exposta às cheias catastróficas.

\section{Bibliografia}

CÂMARA, Duarte B. (1997) - Guia de Campo das Aves do Parque Ecológicodo Funchal e do Arquipélago da Madeira. Funchal, Asssociação dos Amigos do Parque Ecológico.

CARVALHO, A. M. Galopim e BRANDÃO, José M. (1991) GeologiadoArquipélago da Madeira.Lisboa, Museu Nacional de História Natural.

FERREIRA, A. de Brum (1981) - "Manifestações periglaciárias de altitude na ilha da Madeira". Finisterra, 16 (32), pp. 213-229. Lisboa, Centro de Estudos Geográficos.

GOMES, Celso de S. Figueiredo e SILVA, João Baptista P. (1997) - Pedra Naturaldo Arquipélagoda Madeira. Funchal, Madeira Rochas - Divulgações Científicas e Culturais.

HANSEN, A. e SUNDIN, P. (1985) - Flora of Macaronesia. Checklist of Vascular Plants. Oslo, Sommerfeltia n. 1.

HUGGETT, Richard John (1998) - Fundamentals of Biogeography. London and New York, Routledge.

LACOSTE, Alain e SALANON, Robert (1999)-Élements de Biogéographie et d'Écologie (2a Edição). Paris, Éditions Nathan.

MATA, João Manuel L. S. (1996) - Petrologia e Geoquímica das Lavas da llha da Madeira: implicações para os modelos de evolução do manto terrestre. Lisboa, Faculdade de Ciências da Universidade de Lisboa, Centro de Geologia. 
MORAIS, J. Custódio de (1945) - "O Arquipélago da Madeira", Memórias e Notícias (Publicações do Museu Mineralógico e Geológico da Universidade de Coimbra). Tipografia da Atlântida.

NEVES, Carlos Manuel L. B. (1952) - Plano Geral da Orientação Técnica do Montado do Barreiro e do Pisão. Lisboa, relatório dactilografado.

PORTUGAL FERREIRA, M. (1985) - "Evolução geocronológica e paleomagnética das ilhas do Arquipélago da Madeira", Memórias e Notícias (Publicações do Mus. Lab. Min. Geol. Univ. Coimbra). 99, p.213-218.

PRESS, J. R. e Short, M. J. (1994) - Flora of Madeira. London, The Natural History Museum.

QUINTAL, Raimundo (1996) - Laurissilva, A Floresta da Madeira (2a Edição). Funchal, Editorial Correio da Madeira.

QUINTAL, Raimundo (1999) - "Aluviões da Madeira. Séculos XIX e XX”. Territorium 6, pp. 31-48, Coimbra, Minerva.
QUINTAL, Raimundo (1999) - "Inundações no Funchal - Causas e Consequências". Revista ENB, 11, pp. 11-17, Sintra, Escola Nacional de Bombeiros.

RISER, Jean (1999) - Erosão e Paisagens Naturais. Lisboa, Ins. Piaget.

ROBINSON, Andrew (1993) - Earth Shoch. London, Thames and Hudson.

SOUSA, Abílio Barros (1946) - Plano de Arborização do Montado do Barreiro. Funchal, Câmara Municipal do Funchal.

VINK, Gregory E,, MORGAN, W. J. e VOGT, P. R. (1991) "The Earth's Hot Spots". Scientific American, Science in the 20th Century, Special Issue Vol. 3, Number 1.

WILSON, E. O. - organizador (1997) - Biodiversidade. Rio de Janeiro, Nova Fronteira.

ZBYSZEWSKI, G., FERREIRA, O. V., MEDEIROS, A.C., AIRES-BARROS. L., SILVA L. C., MUNHÁ, J. M. e BARRIGA, F. (1975) - Notícia Explicativa da Carta Geológica da, Ilha da Madeira. escala 1/50.000, Lisboa, Serviços Geológicos de Portugal. 
